\title{
DEVELOPING AND IMPLEMENTING HIGHER PROFESSIONAL STANDARDS IN ACCOUNTING
}

\author{
EDMund F. Ingalis*
}

Efforts to promote a greater degree of "uniformity" in financial reporting have been largely centered in the American Institute of Certified Public Accountants, the national professional organization of practicing accountants. In addition to providing the forum for the most effective work yet done in the direction of attaining improvement in accounting principles, the AICPA has achieved much in the way of up-grading the profession generally by work in the fields of legislation, ethics, education, public relations, and standards for admission to practice. The considerable attention being given to current efforts in the area of principles should not obscure these other efforts toward achieving for accountants a clear entitlement to, and recognition of, professional status.

The uniformity movement is the most important development in accounting in recent years and raises significant problems concerning the implementation of the requirements that may emerge from the debate. The methods to be employed by the AICPA and state CPA societies to assure adherence to new and stricter professional standards are far from clear, as the recent flurry over the effect to be given to opinions of the AICPA's Accounting Principles Board amply demonstrates. ${ }^{1}$ Of equal importance is the question of the extent to which the disciplinary power of the professional associations will be used to implement standards laid down by the AICPA. Finally, the manner in which state regulatory machinery might be employed to implement new standards fashioned by the profession ought to be considered. All these questions must be viewed in the light of another sanction that promotes adherence to professional standards-the specter of auditor's liability, a subject that is treated elsewhere in this symposium.

The accounting profession, like other elements in American life, has a preference for self-regulation over regulation imposed from without, by legislation, government agency, or judicial intervention. The mechanics of self-regulation must be considered if the responsibility is to be met in time to avert external control. Maintenance of public confidence in the profession is a concomitant and essential goal.

*A.B. 1938, M.B.A. 1940, Harvard University; LL.B. I953, New York University. Manager of Technical Information Service, American Institute of Certified Public Accountants; member of the New York bar. Author, Practical Accodnting and Auditing Problems-A Guidebook for the ProFEssion (3 vols., forthcoming April, I966). Contributor to The Journal of Accountancy.

The American Institute of Certified Public Accountants, as a matter of policy, disclaims responsibility for any private publication by any of its staff. The views expressed herein are those of the author and do not necessarily reflect the views of the AICPA or any of its committees or of the author's colleagucs on the Institute's staff.

${ }^{1}$ See text accompanying notes $43-60$ infra. 


\section{Organization of the Accounting Profession}

\section{A. Background of the AICPA}

Early momentum towards welding public accountants in the United States into a professional body was largely due to efforts of Scottish and English accountants who came here in the r88os and I8gos to assure accountability for the large amounts of foreign (principally English) investments in this country. ${ }^{2}$ In I886, the American Association of Public Accountants, the predecessor of the AICPA, became the first organized body of professional accountants in the United States. ${ }^{3}$ Legal recognition of the certified public accounting profession was achieved during the years 1896-1913, New York enacting the first legislation in the United States to create the professional designation "Certified Public Accountant" in I8g6. Laws providing for the issuance of the CPA certificate had been enacted in over thirty states by I9I3. Starting with fifty-six CPA certificates in 1896 , a total of 85,852 original certificates had been issued by all the states through $195^{8.5}$ There are now about 9r,000 CPAs.

Following passage of the first CPA law in New York, a number of state associations were organized to sponsor similar legislation in their own states. These state groups soon formed the Federation of Societies of Public Accountants. In I905, the American Association of Public Accountants and the Federation merged and retained the federation form of organization. However, in 1916 , the Association was reorganized as the American Institute of Accountants (later to become the AICPA). Sponsors of the reorganization contended that the federation form of organization was a roadblock to development of a strong national organization, establishment of common standards of qualification throughout the country, and enforcement of a uniform code of ethics.

Only five years later, a rival organization, the American Society of CPAs, was formed, and from I921 to 1937 contended with the Institute primarily over the desirability of a strong national professional association. John L. Carey, Executive Director of the AICPA, has referred to the organizational schism as follows:

The Society was devoted to support of the CPA certificate as the recognized professional qualification-as contrasted with Institute membership. The Society was also dedicated to states' rights, and its structure and operating procedures more closely resembled those of a federation than those of a centrally administered national organization.

For fifteen years, the Society and the Institute competed for support of the

\footnotetext{
${ }^{3}$ See James D. Edwards, History of Public Accounting in the United States 53 (1960).

${ }^{3}$ Id. at $52-55$.

1. 1 . at 72 .

Id. at $362-63$.
} 
CPAs of the United States. They differed widely on basic policy questions; they took contrary positions on public issues. Much bitterness was engendered. ${ }^{0}$

Merger of the Society and the Institute on a compromise platform in 1937 paved the way for rapid membership growth and allowed the profession to speak once more with one voice.

Today, the AICPA's membership of 54,000 represents almost sixty per cent of the total number of CPAs. Sixty-eight per cent $(37,000)$ of the membership is engaged in public accounting practice, with thirty-two per cent $(\mathrm{r} 7,000)$ otherwise employed (in corporate, university, and government positions, among others). About thirty-five per cent of the Institute's members in public practice (or some Io,900) are in 150 of the 12,359 firms represented in the Institute membership.

The AICPA has a president and other annually elected officers. The Council, consisting of over 200 members, is designated in the Institute's by-laws as the governing body of the Institute. The number of its elected members is based on each state's proportional representation within the Institute's membership; and each state society also has a representative on the Council. The Executive Committee is an arm of the Council, elected by the Council from among its own membership. The Council has delegated authority to senior committees to issue pronouncements in the areas of accounting principles, auditing procedure, ethics, and taxation, and has empowered a number of satellite committees and boards to administer certain other projects. The Institute's staff, which now totals about 200, is headed by the Executive Director. Organizationally, the Institute has a number of divisions, dealing with such matters as Accounting Principles Board Administration, Accounting Research, Education and Examinations, Federal Government Relations, Professional Development, Professional Relations, Publications, and Technical Services.

\section{B. Legal Status of the AICPA and State CPA Societies}

Boards of accountancy are officially constituted state administrative or licensing bodies, generally endowed with statutory power to make reasonable regulations controlling the practice of public accountancy and to take disciplinary actions, including, in some cases, deprivation of the right to practice for proper cause. As presently established, the state boards may not irrevocably delegate their authority or official responsibilities.

State societies of CPAs are privately-organized associations and are not "integrated" with the official state boards, as some state bar associations and state or county medical societies are "integrated" with their official counterparts. In Great Britain and Canada, the requirements for qualification as a Chartered Accountant are administered by professional societies. However, in the United States, while professional societies (principally the AICPA, as we will later show) have played an important role in the development and promulgation of admission and other stan-

\footnotetext{
${ }^{6}$ John L. Carey, The CPa Plans for the Future 515 (1965). See generally id. at 513-19.
} 
dards, legislative recognition of public accountancy has become the standard procedure.

The state CPA societies and the AICPA are independent, autonomous bodies, having no legal relationship to each other. Their respective members are not required to be members of both.

The AICPA is organized under the laws of the District of Columbia as a nonprofit professional membership corporation. The legal problems confronting a nongovernmental professional association of this kind in effectively enforcing its charter and by-laws and its ethical and technical rules and pronouncements, and in carrying out disciplinary actions against its members, are summarized later in this paper.

\section{II}

\section{The Regulatory Pattern}

\section{A. State Regulation}

State legislation concerning accountancy embraces primarily the categories of admission requirements, ethics, and interstate rights to practice. Although some progress toward unification of standards has been made over the years, by and large the plurality of jurisdictions involved has resulted in anachronistic disparities in standards and requirements. ${ }^{7}$ There is no national accountancy law, nor is there a national license for the practice of public accountancy in all states. Clifford V. Heimbucher, in a well-wrought and thoughtful article written at the time he was a member of the AICPA's Committee on Long-Range Objectives, has analyzed in some detail the multiform provisions of state laws. ${ }^{8}$ He demonstrates how statutes may be characterized as either "regulatory" or "permissive" and how distinctions between the two types of laws and other factors produce registration variations, differences in the definitions of public accounting practice, and disparity and confusion in the signification of the titles used by accountants in various jurisdictions.

Under the so-called permissive laws, in effect in seventeen jurisdictions, anyone may undertake public accounting engagements, that is, do public bookkeeping and write-up work, prepare federal and state tax returns, audit accounting records, prepare financial statements, and express opinions as to the fairness of their presentation. The only thing a public accountant may not do under a permissive accountancy statute is hold himself out as a certified public accountant.

\footnotetext{
${ }^{7}$ For details of accountancy statutes and regulations (education, examination, experience, reciprocity, temporary practice, and registration requirements), covering all states and territories, see $\mathrm{CCH}$ AccounTANCY L. REP. For an annotation discussing the judicially-determined principles of law pertaining to the accountancy profession including regulation, rights, duties, and responsibilities of accountants, and relation to their clients, see I AM. Jur. 2d, Accountants $\$$ I-2I (I962).

${ }^{8}$ Heimbucher, Fifty-three Jurisdictions, J. Accountancy, Nov. I96r, p. 42. See also Provissons is CPA Laws and Regulations (1963) (prepared by U.S. Army Audit Agency in cooperation with the AICPA).
} 
Regulatory laws, on the other hand, govern the practice of both CPAs and nonCPAs. In twenty-seven of the thirty-six jurisdictions with regulatory-type accountancy statutes, only those noncertified accountants who were engaged in public accounting practice as their principal occupation at the time of enactment of the law are permitted to practice and to hold themselves out as public accountants. As matters presently stand in these jurisdictions, no additional non-CPAs will be admitted to practice in the future. Regulatory laws vary from, on the one hand, those that contain detailed definitions of public accounting and list services that no one but registrants may perform, to those that do not attempt to define public accounting but simply restrict to licensees the use of professional titles and the expression of opinions on financial statements. Under the latter regulatory-type law, unlicensed persons may still engage in public accounting, provided they do not use the proscribed titles or express an opinion on a financial statement.

Although the uniform CPA examination now in use in fifty-three jurisdictions is a notable accomplishment, considerable divergencies in minimum formal educational and experience requirements prevail. In 1965, thirty-two jurisdictions still allowed high school graduation as the minimum educational level prerequisite to sitting for the examination. With the medical and legal professions, and top positions in the teaching and scientific professions, requiring graduate work leading to a terminal degree, discerning CPAs are well aware what low standards in this area mean from the standpoint of achieving professional status. The difficulty is not overcome by the fact that a large majority of all those receiving certificates, including those in the low-standard jurisdictions, are actually college graduates.

Also, nothing approaching a national uniformity of interstate rights to practice yet exists. Heimbucher points out that "in twenty-four jurisdictions a place of business within the state does not fulfill the residence requirement, actual personal domicile being mandatory." $\mathrm{He}$ refers to other "arbitrary" and "petty" bars to reciprocity certificates erected by some states and concludes that "in the area of interstate practice the diversity of rules and legal rights and prohibitions reaches an absurdity."10

State laws also reflect diverse approaches to ethical standards and their enforcement. Jurisdictions having permissive statutes provide no substantial means of enforcing professional ethics. In addition, Heimbucher notes that, while thirty-six jurisdictions have legal codes of ethics, only twenty-four of these have codes that "may be considered fully enforceable in the sense that a violation may result in the revocation of the license to practice public accounting."11 He also points out that

\footnotetext{
${ }^{\circ}$ Heimbucher, supra note 8 , at 45 .

${ }^{10}$ Ibid.

${ }^{11}$ Ibid. For another pertinent discussion, see Gibbs, Problems Arising in Connection with Enforcement of Rules of Professional Conduct by State Boards, in Association of CERTIPIEd Public Accountant Examiners, Proceedings of the I956 Annual Meeting 20; see also Foye, Cooperation Between State Societies and State Boards of Accountancy, in id. at 28.
} 
"legal enforcement procedures and effectiveness also vary widely from state to state." 12

AICPA tabulations show that codes of ethics adopted by state societies of CPAs have reached what is judged to be about seventy per cent substantial uniformity with the AICPA's Code of Professional Ethics. This fact, of course, implies nothing about the extent to which state societies have applied sanctions against violators or, for that matter, about any widespread need for applying the same. It is clear, however, that ethical uniformity at both national and local levels is a necessary underpinning for the maintenance of high auditing standards. Moreover, as will be emphasized later, unless there is widespread adherence to generally accepted auditing standards, talk of implementing uniform accounting principles and reporting standards becomes a somewhat academic exercise. With three jurisdictional levels for enforcing ethical rules all in various stages of development (i.e., the AICPA, the state societies, and the state boards), there should be some established clearinghouse procedure for interchanging and summarizing information respecting cases involving ethical infractions. As far as I have been able to ascertain, there is no information currently available that would afford one an overview of enforcement activity in this area. ${ }^{13}$

On the basis of the foregoing, it should not be concluded that the AICPA has stood idly by in the matter of state legislation. To be sure, it had approached state legislation gingerly over a course of years. However, the Institute's Council, in 1956, abandoned its neutrality policy on state laws and declared an official policy in favor of regulatory legislation. In so doing, it approved a statement of nine carefully drawn legislative principles. ${ }^{14}$ In the same year, the Institute's committee on state legislation, with the assistance of legal counsel, drafted a recommended "Form of Regulatory Public Accountancy Bill."15 In addition, the Institute has done much to promote uniformity in educational requirements ${ }^{16}$ and has also recently formulated and recommended a flexible and enlightened policy on experience requirements. ${ }^{17}$ It is important to point out that the difficulties and obstacles faced

\footnotetext{
${ }^{22}$ Heimbucher, supra note 8 , at 45.

${ }^{13}$ For some down-to-earth comments regarding the subtleties of state board enforcement of ethical rules and the problem of close collaboration in this area between state societies and state boards, see the articles by Gibbs and Foye, stipra note II.

${ }^{14}$ See address by Ralph S. Johns, Sttmmary of Institute Legislative Policy, before Annual Meeting of AICPA, New Orleans, Oct. 1957.

${ }^{25}$ Reprinted in $2 \mathrm{CCH}$ Accountancy L. Rep. 165101.

${ }^{10}$ For a report marking a historic juncture for the profession, see Commission on Standards of Education and Experience for Certified Public Accountants, Standards of Education and Experience for Certified Public Accountants (1956). The Institute's educational policies, as they now stand, are detailed in Educational and Professional Training, J. Accountancy, March 1963, p. 87. But see also note 30 infra.

${ }^{17}$ See Resolutions on Education and Experience for CPAs Adopted by the Council of the American Institute of CPAS, April 22, 1959, J. Accountancy, June 1959, p. 66; SPEcial COMM. ON the Report of the Commission on Standards of Education and Experience for CPAs, AiCPA, Report to Council (1959), in J. Accountancy, June 1959, p. 67, at 70. See also CoMmittee on Qualifying Experience for the CPA Certificate, AiCPA, Report to Council (1960).
} 
by the Institute in achieving substantial uniformity of legislative standards relating to the accounting profession run parallel to those encountered in attempts at unification of law in other areas.

\section{B. Improvement in State Regulation or Federal Control?}

Serious question might well be raised whether time is beginning to run out in achieving high uniform standards in state regulation of accountancy. Possibly the slow state-by-state approach employed in the past has now become an anachronistic drag on the achievement of unquestioned professionalization. Literally scores of addresses have been made over the years urging greater "integration" of state societies with state boards of accountancy and further meshing of local standards with the Institute's standards on education, experience, interstate rights to practice, and ethics, but progress has been slow despite a deliberate articulation of Institute policies in all these areas, especially during the last decade. One of the most forceful calls for a consistent program of action in this area is contained in a recent committee report approved by the AICPA's Executive Committee on September $5,1963 .{ }^{18}$ The report recommended a detailed Institute policy and broad program of action under such headings as "Education of State Society Members in Desirability of Uniformity," "Education of State Society Members in Techniques of Fostering Legislation," and "Solicitation of State Society Action to Adopt Form Bill and AICPA Code of Professional Ethics."

Clifford V. Heimbucher has raised the question whether nationalization of the certificate might meet the need for a breakthrough to uniform standards in this area. ${ }^{19}$ In this connection, it is of more than passing historical interest to point out the following passage from Edwards' History of Public Accounting in the United States. In discussing the period $1896-19 \mathrm{I} 3$, he states:

Many of the prominent practicing public accountants in these years felt that the profession of accountancy needed federal recognition and regulation. They based their argument largely on the fact that accountancy was to a very large extent interstate. All of the large firms of public accountants, the arguments went, practiced in more than one state-in some cases in foreign countries. If the accountant could receive recognition from the national government, he would be able to practice in interstate commerce without hindrance. The profession desired a license which all states would recognize. It was pointed out by Sells that no comparable difficulty existed in the practice of the professions of law and medicine, neither of which, generally speaking, was of the same interstate character as the profession of accountancy. ${ }^{20}$

The following observations made in $195^{6}$ by the Commission on Standards of Education and Experience for CPAs are also pertinent:

\footnotetext{
${ }^{18}$ Committee on Uniformity of Legislative and Other Standards Governing Practice, AicPa, REPORT TO COUNCIL (1963).

${ }^{10}$ Heimbucher, supra note 8 , at $48-49$.

${ }^{20}$ EDWARds, op. cit. supra note 2, at 70. (Footnote omitted.)
} 
Uniform national standards also represent a desirable objective in terms of facilitating public accounting practice as it presently exists. In order to serve a client with multi-state plants or offices, it is common for a public accounting firm to practice in many states. The interstate character of public accountancy has also been influenced by activities of agencies of the Federal government which are themselves national in scope. The Internal Revenue Service, Securities and Exchange Commission, and utility and common carrier regulatory agencies are particularly important in this connection. ${ }^{21}$

The question of federal enactment of a uniform legislative standard is no mere academic question and should be discussed objectively and dispassionately within professional circles. It is by no means beyond the realm of possibility that "events" could force this issue. In an address delivered in the spring of $196_{5}$, $^{22}$ the Chief Accountant of the SEC, Andrew Barr, referred to the greatly increased number of SEC filings resulting from (a) the amendment in May I964 of Proxy Rule I4a- $3^{23}$ under the Securities Exchange Act of 1934, (b) the Securities Acts Amendments of Ig64 involving extension of registration and reporting requirements to many companies having unlisted securities, ${ }^{24}$ and (c) the requirement of the $196_{4}$ amendments that unlisted insurance companies under certain conditions file financial reports with their state regulatory commissions ${ }^{25}$ and that certain banks file financial reports with the appropriate bank regulatory agency. ${ }^{26} \mathrm{He}$ points out that although certification by independent CPAs is not required of the banks, the rules as adopted encourage it. ${ }^{27} \mathrm{Mr}$. Barr also referred to an informal survey ${ }^{28}$ reporting a definite trend for the federal government as a whole toward reliance on the accountant's attest function through increased use of independent audits. It is estimated that 38,000 audits are stimulated or used by just twenty-six federal agencies each year as compared to about half that number five years ago; the SEC is the biggest user, with some $I I, 825$ annually. A more recent report reveals SEC testimony to congressional committees to the effect that independently audited over-the-counter filings will increase from 1300 to 2200 in the year ahead, and that similarly audited proxy filings will jump from 2500 to 5000.29 The potentiality for pressure for some federal control of the accounting profession is apparent.

\footnotetext{
${ }^{2}$ Commission on Standards of Education and Experience for Certified Public Accountants, op. cit. stipra note 16 , at 38 .

${ }^{33}$ See address by Andrew Barr, Trends in Financial Reporting, before the I9th Annual Conference of Accountants at the University of Tulsa, April 29, I965, excerpts reprinted in J. Accountancy, July 1965 , p. 55 .

${ }_{23}{ }_{7}$ C.F.R. $\$ 240.14 a-3$ (Supp. I965).

${ }^{24} 78$ Stat. 566 ( 1964$)$, 15 U.S.C. $\$ 78 l(g)(\mathrm{r})(1964)$.

${ }_{7}^{26} 8$ Stat. 567 (I964), 15 U.S.C. $\$ 78 l(g)(2)(G)(1964)$.

${ }_{78}^{20}$ Stat. 567 (1964), $x_{5}$ U.S.C. $\$ 78 l(\mathrm{i})(1964)$.

${ }_{27} 30$ Fed. Reg. $364,372-74$ (1965), adding I2 C.F.R. $\$ \$ 206.2$ (dd), .7 (Federal Reserve Board); 30 Fed. Reg. 397, 406-08 (1965), adding I2 C.F.R. $\$ \$ 335.2$ (dd), .7 (Federal Deposit Insurance Corp.). ${ }^{28}$ See Bryan, Growth in Federal Audits, J. Accountancy, Oct. I964, p. 32.

${ }^{20}$ Hearings on Independent Offices Appropriations for 1966 Before a Subcommittee of the House Committee on Appropriations, 8gth Cong., Ist Sess., pt. I, at 157-59 (I965) (testimony of Commissioner Byron D. Woodside).
} 
One thing seems patent: that substantial uniformity of high legislative standards would do more than any other influence in clarifying the meaning of the CPA certificate and making it not just a mere license to practice but rather a definitive mark of technical attainment and competence. ${ }^{30}$

\section{III}

\section{The AiCPA and Professional Standards}

The lack of uniformity among state laws and the uneven administration of the laws that exist have placed a major share of the burden of supervising professional conduct on the AICPA and the state societies. The disciplinary powers of these organizations are considerable, consisting of powers of suspension or expulsion from membership. The practical effects of these sanctions vary with the kind of practice an accountant is engaged in but are in most cases considerable enough to serve as a deterrent to unprofessional conduct.

\section{A. Development of Ethics; The Role of the Committee on Professional Ethics}

As a supplement to the disciplinary clauses of its by-laws, the AICPA, in recognition of the importance of the exercise of moral leadership and of internal control of its membership in achieving true professionalization, has developed over the years a series of rules of professional conduct. In I 962 these rules were cast into a revised Code of Professional Ethics, ${ }^{31}$ which specifies the expected professional standards to be observed in the CPA's relations with clients, the public, and with fellow CPAs, the technical standards that govern his work, and the CPA's operating practices. The "generally accepted auditing standards" commonly referred to in the CPA's standard short-form report are fundamentally ethical standards enforceable by Institute action against its members. Not only this, the auditing standards are probably the basic source of the standards to which a court will look in a malpractice or negligence action.

"Generally accepted auditing standards" may be classified broadly into (a) general standards-adequate technical training and proficiency, maintenance of an independent mental attitude, and exercise of due professional care; (b) field-work standards-adequate planning and supervision of work, evaluation of internal control as the basis for determining the nature and extent of audit tests, and

\footnotetext{
${ }^{30}$ The "Study of the Common Body of Knowledge for CPAs," a project of the Institute which is currently nearing completion, should prove to be another historical landmark in defining educational and competence levels requisite for the modern practice of public accountancy. Sce Ramanauskas, The Common Body of Knowledge for Accountants, The Illinois CPA, Winter 1964, p. 1. Sce also Lynn, Education and Professional Training, J. Accountancy, March 1963, p. 87, at 88 .

${ }^{32}$ For pertinent material (including the current text of the Code), see JoHN L. Carey \& William O. Doherty, Ethical Standards of the Accounting Profession (ig66); see also Darwin J. Casler, The Evolution of CPA Ethics: A Profile of Professionalization (Bureau of Business and Economic Research, Michigan State University, Occasional Paper No. 12, 1964); John Peoples, Discipline and Enforcement (AICPA Annual Meeting paper, I963).
} 
obtention of sufficient competent evidential matter to afford reasonable basis for an opinion; and (c) reporting standards-conformity of financial statements with "generally accepted accounting principles," consistency of observance of such principles, adequacy of informative disclosure, and adherence to standards governing the expression of an unqualified opinion on statements or requiring qualification, disclaimer, or adverse opinion thereon, together with a statement of the reasons therefor. ${ }^{32}$

Authority over ethical matters is lodged in the AICPA's Committee on Professional Ethics. This Committee recommends changes in the Code and has issued to date some seventeen numbered opinions that interpret and apply the Code provisions to practical situations. The Committee is also charged with investigating all complaints against Institute members. If the Committee believes that a member has violated the Code, he is summoned before the Trial Board, which may acquit, admonish, suspend, or expel him. While disciplinary cases referred to the Trial Board currently approximate only about one tenth of one per cent of the total membership, the twenty-one-man Trial Board was decentralized in 1963 better to accommodate a possible increased volume of cases. Now, the Trial Board chairman may appoint a sub-board of five members to hear a case at a convenient time and place.

In May 1960, the Institute's Council adopted as one of its formally-stated objectives the following:

It is an objective of the Institute that by voluntary agreement the plans, programs, procedures and activities of the state societies and the Institute be coordinated to the fullest extent possible, and their respective areas of responsibility be clearly delineated; and in particular that the state societies and the Institute adopt a uniform code of ethics and enforcement procedures. ${ }^{33}$

Pursuant to the foregoing, the Institute's Committee on Professional Ethics is giving increasing consideration to the matter of improved coordination and communication between the Institute and the state societies. Two points in particular have had attention: (I) development of a procedure whereby the Institute would take the lead in dealing with complaints that may involve practice before federal agencies, interstate practice, and other questions of national concern, as well as ethics questions that touch on the broader issues of accounting principles and auditing procedures, while leaving the state society committees in a position to deal with complaints regarding directory listings, advertising, solicitation, and the like; and (2) development of a procedure providing for notification between the Institute and state societies when serious charges have been made. The Institute has given serious consideration to seeking implementation of the latter based on legal opinion

\footnotetext{
${ }^{32}$ Committee on Auditing Procedure, Aicpa, Auditing Standards and Procedures 15-16 (Statement on Auditing Procedure No. 33, I963).

${ }^{33}$ Emphasis added.
} 
that a professional association may properly release to another professional association information that might under other circumstances be deemed confidential, provided that the other professional association in question has a legitimate interest in the subject matter and so long as it may not be shown that release of the information is actuated by malice.

An amendment of considerable importance was written into the Institute's Code in the 1962 revision. The amendment was a much more stringent rule on independence, which largely, except for different attitudes concerning so-called "writeup work," coordinates the Institute's view on this matter with SEC policy. ${ }^{34}$ Another amendment, adopted in 1958 and made a part of the Code, incorporates, in effect, the Institute's reporting standards. ${ }^{35}$ This marks an important milestone in the uniformity movement. A later proposed amendment to this part of the Code is dealt with further below.

The scope of the power of the Institute and the state societies to enforce sanctions against their members is in some ways limited by law. While this is not the place to examine the requirements of "private administrative law" in detail, a summary of legal principles is desirable. The disciplinary actions referred to in the following discussion are the professional association's suspension and expulsory powers.

\section{B. General Legal Principles Governing Disciplinary Proceedings ${ }^{36}$}

Generally speaking, a court will not enjoin expulsion proceedings pending before a professional association so long as the corporate authorities are acting intra vires. Refusal of an injunction against an expulsion hearing is usually based on the view that expulsory tribunals of professional associations are deemed to be courts of special or limited jurisdiction, and their proceedings are regarded as quasi-judicial in nature.

Neither will a court as a general rule retry a case upon the facts or make its own judgment as to whether or not the member should have been expelled. A court's interference with disciplinary matters of a professional association is limited to certain stated grounds involving fundamental rights. Thus, a court generally will give a remedy, and review expulsory proceedings, when it can be shown prima facie that the expulsion was in violation of notions of procedural due process, which

\footnotetext{
31 AICPA, Code of Professional Ethics, Rule I.ox.

${ }^{35}$ AICPA, Code of Professional Etrics, Rule 2.03.

${ }^{30}$ Authority for all statements herein respecting the law generally applying to disciplinary procecdings of professional associations, together with case citations, may be found in Annot, 20 A.L.R.2d 53r (195I). For other annotations of interest in this connection, see Annot., I37 A.L.R. 3II (I942) (mandamus against unincorporated association or its officers); Annot., 92 A.L.R. 1029 (1934) (libel and slander: qualified privilege as regards publication of matters in relation to members of private or quasi public bodies in newspapers or journals; Annot., I4 A.L.R. I446 (I92I) (right of association to expel or discipline member for exercising a right, or performing duty, as a citizen); Annot., 3 A.L.R. I654 (I9I9), and I5 A.I.R. 453 (I92I) (libel and slander: privilege of communication in relation to member, or prospective member, of society, other than church).
} 
permit a court to pass upon the question whether an expulsion proceeding was sufficiently "regular" to ensure substantial justice. Accordingly, a court would intervene where there was a denial of a fair hearing or lack of proper notice either as to the hearing or as to the nature of the charges. Courts may also consider on their merits charges that the expulsion was voted arbitrarily, or in bad faith or with malice, or was not actually for the cause alleged in the charge or that the tribunal was not regularly constituted or properly composed (for example, because of failure to disqualify certain members for bias or prejudice). While the courts generally will not pass on the weight of the evidence, they will determine what, if any, evidence was presented and whether it appears that the charges are totally unsustained.

A second basis for judicial review of expulsion proceedings is possible invalidity under public policy of provisions in an association's constitution, charter, by-laws, or rules and regulations under which the disciplinary action is taken. In certain cases involving medical societies, for example, courts have reinstated a member expelled because he engaged in actions favored by public policy. It has also been held that expulsory regulations are to be strictly construed because they are penal in nature and may involve forfeiture of valuable rights. Questions have also been raised as to whether a by-law fixing fees and a regulation forbidding members' consultation with an expelled member are void as being contracts in restraint of trade. Generally speaking, however, if regulations are adopted in pursuance of the legitimate objects of a professional association, they are not deemed void as being coercive of its members because of the threat of expulsion involved.

Legal recognition of a professional membership association's powers of expulsion and suspension is bottomed on a contract between the association (incorporated or unincorporated) and its members. The terms of the contract are to be found in the constitution or charter of the association and its by-laws, regulations, membership application, conventions, and so forth. In becoming a member, one assumes all the obligations of membership, binds himself to observance of the defined standards, and submits to the expulsory and suspensory jurisdiction of the association.

As for judicial remedies for wrongful expulsion and related wrongs, the great majority of jurisdictions will give specific relief (even though no severable pecuniary or proprietary interest is involved), generally on the ground that corporate membership is a property or civil right or that membership involves valuable privileges and rights, both educational and professional. Mandamus, which is normally available only to enforce performance of public duty, is another possible remedy for wrongful expulsion from an incorporated professional association and is available on the ground that valuable rights amounting to a franchise are involved and that a professional membership corporation is a public functionary in which the whole community has an interest. It is generally held that disciplined members must exhaust their remedies within the organization before they can have resort to the courts. 
The fact that actions for libel and slander have been brought for defamatory words used in connection with a prospective or actual expulsion has given pause to many professional associations. However, defamatory statements made in the course of disciplinary proceedings within the jurisdiction of a professional association are generally held to be qualifiedly privileged. Thus, complaints and accusations by members respecting unprofessional conduct and the production and discussion of evidence are protected if done in good faith and without malice and in bona fide discharge of a duty arising from membership. It has been held that fair accounts of accusations and proceedings of expulsion published by professional associations for the information of the profession and of the public are privileged as being reports of quasi-judicial proceedings.

IV

\section{The Profession's Role in the Development and Implementation of Increased Uniformity in Accounting Principles}

As a prelude to discussion of the part to be played by the Institute in the further clarification, development, and delimitation of generally accepted accounting principles, it is important to record briefly the past accomplishments of the professional leadership in the technical areas of auditing standards and accounting principles. To discuss the question of achieving "uniformity" of accounting principles without explicit recognition of the solid progress on fundamentals that has been achieved in the past would be misleading and might imply that the pursuit of improvement in this area is a new development. The pressures for uniform standards and for delineation of proper accounting principles have always existed and have been the abiding concern of the profession during the whole course of its development.

\section{A. Highlights of the Historical Development of Auditing Standards and Accounting Principles}

The earliest efforts at making accountancy function with some uniformity were by individuals. ${ }^{37}$ The achievements of professional organizations were modest at first due to their limited authority, but began in earnest with the Institute's preparation of a series of two pamphlets on auditing procedure for publication by the Federal Reserve Board and the Federal Trade Commission; interestingly enough,

\footnotetext{
${ }^{37}$ Brundage, Milestones on the Path of Accounting, Harv. Bus. Rev., July 1951, p. 7r, traces some of the distinguished early contributions of individual CPAs: that of Arthur Lowes Dickinson during the merger movement at the turn of the century, especially his contribution towards devising consolidated statements "to eliminate intercompany transactions and to present a single composite picture of the combined operations of affiliated companies" (id. at 72); Joseph E. Sterrett's part in helping to draft some of the provisions incorporated in the Revenue Act of rgr 8 (id. at 74); and authoritative texts on accounting published in 1908 and $x 909$ by Robert H. Montgomery, William M. Cole, Charles Ezra Sprague, and Henry R. Hatfield. See also Brundage, Roadblocks in the Path of Accounting, Harv, Bus. Rev., Sept. r95r, p. rio.
} 
the title of the first publication was Uniform Accounting, ${ }^{38}$ the subject being, however, not so much principles as auditing procedures.

The stock market debacle of 1929 and the passage of the federal securities laws generated greatly increased interest in the quality of financial data supplied the public and accelerated institutional efforts within the accounting profession. Committees of the Institute and the New York Stock Exchange had extended correspondence between 1932 and $1934,{ }^{39}$ which resulted in the sponsorship of an approved version of the accountant's short-form report and adoption by the Exchange of a requirement for annual independent audits.

The emergence of the SEC prompted concern over whether that body would proceed by decree in the area of accounting practices or would defer in matters of judgment to the collective wisdom of the accounting profession. The SEC commenced to issue its Accounting Series Releases in 1937, stating that its purpose was to contribute "to the development of uniform standards and practice in major accounting questions." ${ }^{340}$ While I02 such releases have been issued to date, the Commission has left the major part of the responsibility for improvement in accounting principles to the profession itself. ${ }^{41}$

The Institute's efforts are well known. Formal machinery for the purpose of formulating auditing standards and accounting principles was established about the time the SEC became active in accounting matters. The Committee on Accounting Procedure was set up in 1937 and had published fifty-one Accounting Research Bulletins by 1959, when it was superseded by the Accounting Principles Board. ${ }^{42}$ The Committee on Auditing Procedure was established in 1939 and since then has handed down thirty-four authoritative Statements on Auditing Procedure.

The revision of the Institute's research program in 1959, which featured the establishment of the Accounting Principles Board and the Institute's Accounting Research Division, reflected a step-up in the pace of progress and was by no means a change of direction. What is new, however, is the greatly increased scope of the research being done (witness the eight Accounting Research Studies that have appeared to date), the increased staff, and the injection of fresh and experimental viewpoints. Also of prime importance is the new effort being made to rationalize

\footnotetext{
${ }^{38}$ Uniform Accounting: A Tentative Proposal Submitted by the Federal Reserve Board (I9I7) [the title was later changed to Approved Methods for the Preparation of Barance-Sheet Statements (IgI8) and still later to Verification of Financial Statements (1929)]. The pamphlets were revised in 1936 and published as AICPA, Examination of Financtar Statements By IndePENDENT PUBLIC Accountants (I936).

39 American Institute of Accountants, Audits of Corporate Accounts (r934).

${ }^{10}$ SEC Accounting Ser. Release No. I, April I, I937.

${ }^{1}$ See generally Pines, The Securities and Exchange Commission and Accounting Principles, supra, pp. 727-5I.

"For an unusual case involving an unsuccessful attempt by third parties (three utility companies) to have the court enjoin the AICPA from construing a term used in one of its Accounting Research Bulletins and formally communicating such interpretation to its membership, see I ARTHUR ANDERSEN \& Co., Cases in Poblic Accounting Practice (ig60).
} 
and clarify research objectives and to obtain the views of interested groups by a considerably expanded circulation of exposure drafts.

In sketching the foregoing, we have necessarily omitted discussion of the considerable technical benefits accruing from relations of special Institute committees with federal government agencies, the New York Stock Exchange, and various industrial and professional groups. It is also necessary to note in passing the vital contributions made toward enhancement of professional standards by the Institute's standing Committee on Federal Taxation, the continuing Professional Development Program, and The Journal of Accountancy, circulation of which has grown from I4,815 in 194 I to about IIo,000 in I965.

\section{B. The Status of Accounting Principles Board Opinions}

The development of accounting principles by the Accounting Principles Board (APB) has led to serious difficulties with respect to the authority that AICPA members must accord to its pronouncements. The refusal of some accountants to go along with the APB's Opinion No. 2, relating to the proper accounting for the investment tax credit, ${ }^{43}$ highlighted this problem. The issue is a long-standing one and one that requires satisfactory solution before Institute efforts in the direction of increased uniformity can be availing. The recent developments that are recounted here have produced a solution of sorts. Whether the issue is settled for all time remains to be seen.

For many years the authority of Accounting Research Bulletins has rested upon their "general acceptability," but those Institute members who departed from Bulletin recommendations have had to be prepared to assume the burden of justifyng such departure. This was explicit Institute policy. ${ }^{44}$ But in recent years, there have been strong winds of change blowing in the direction of increasing the binding effect of the bulletins and of the pronouncements by the Accounting Principles Board. In an annual meeting address in 1957, Alvin R. Jennings, the AICPA Presidentelect, sowed a seed with the suggestion that bulletins based on adequate research and containing specific committee recommendations should be submitted to the Institute Council and, upon receiving approval of two-thirds of the members of the Council, should be considered binding upon members of the Institute. A Special

\footnotetext{
43 Accounting Principles Bonrd, AICPA, Accounting for the "Investment Credit" (Opinion No. 2, 1963). See Sprouse \& Vagts, The Accounting Principles Board and Differences and Inconsistencies in Accounting Practice: An Interim Appraisal, supra pp. 706-26.

14 For example, Commitree on Accounting Procedure, AiCPA, Restatement and Revision of Accounting Research Bullettins 9 (Accounting Research Bull. No. 43, 1953) and all prior Accounting Research Bulletins contained the following language:

"Except in cases in which formal adoption by the Institute membership has been asked and secured, the authority of opinions reached by the committee rests upon their general acceptability. The committee recognizes that in extraordinary cases fair presentation and justice to all partics at interest may require exceptional treatment. But the burden of justifying departure from accepted procedures, to the extent that they are evidenced in committee opinions, must be assumed by those who adopt another treatment."
} 
Committee on Research Program appointed to look into the matter specifically rejected this proposal, in part on the ground that the Council was too large and unwieldy a body to deliberate effectively on technical matters. Instead, a charter to govern the Accounting Principles Board was recommended by the Special Committee and adopted by the Council. The charter emphasized that the general purpose of the Institute should be "to advance the written expression of what constitutes generally accepted accounting principles, for the guidance of its members and of others." ${ }^{25}$ It also referred to "a continuing effort to determine appropriate practice and to narrow the areas of difference and inconsistency in practice," and went on to state that, in accomplishing this, "reliance should be placed on persuasion rather than on compulsion." ${ }^{36}$

However, in October 1963 , the Institute's Executive Committee recommended to the Council "the adoption of a statement which in essence would declare that a pronouncement of the Board constituted generally accepted accounting principles for purposes of expressing an opinion on financial statements unless and until rescinded by the Council."47 The Accounting Principles Board had previously submitted to the Executive Committee a proposal "that the auditing standard on reporting and the Institute's Code of Professional Ethics be amended . . . to provide that in addition to the obligation to report departures from generally accepted accounting principles, members be obliged to report departures from opinions of the Accounting Principles Board."48 The Executive Committee had looked upon its October 1963 recommendation as "an alternative approach" to that of the APB in "establishing the force and effect of the Board's pronouncements." in what subsequently developed, not only was there a substantial wedding of both proposals, but the amalgamated proposal was carried much further. A Special Report of the Executive Committee issued on March I4, I964, included a complete and informative prospectus setting forth detailed provisions for implementing the substance of the aforementioned proposals. ${ }^{50}$

The Special Report contained a proposal for an amendment to Rule 2.02(e) of the Code of Professional Ethics, ${ }^{\text {,1 }}$ which might have been drafted to read along the following lines (with appropriate emphasis supplied):

\footnotetext{
"SQuoted in Special Comim. on Research Program, AicPA, Report to Counctl (1959), in J. Accountancy, Dec. 1958, p. 62.

${ }^{10} I d$. at $62-63$.

"Quoted in Executive Comen, AICPA, Status of Pronouncements of Accounting Princtiples BonfD I (Special Report, 1964).

${ }^{4}$ Ibid.

40 Ibid.

${ }^{50}$ Executrve Conm., op. cit. supra note 47. For the arguments pro and con the proposal and an opinion of counsel thereon, see id. at $16-29,33-39$ (apps. A and B); see also panel discussion, The Future Self-Regulation of the Profession and the Accounting Principles Board, before the Illinois Society of CPAs, June Io, 1963 (comments by Herman W. Bevis); Higgins \& Bevis, Generally Accepted Accounting Principles-Their Definition and Authority, N.Y.C.P.A., Feb. 1964, p. 93.

${ }^{01}$ Executrve CoMm., op. cit. stupra note 47 , at II-12.
} 
(a) A Board pronouncement in any subject area is deemed to constitute the only generally accepted principle(s) for purposes of expressing an opinion on financial statements, unless or until later rescinded by the Board or Council;

(b) An auditor, contrary to his own professional judgment, is neither bound to declare that financial statements conforming to a Board pronouncement present fairly nor required to declare that statements not conforming to Board pronouncements are not fairly presented; but be that as it may, said auditor (as an Institute member) is bound to disclose any departure from a Board pronouncement and state that, with respect to such departure, the financial statements do not conform to generally accepted accounting principles;

(c) However, an auditor is not forbidden from expressing an opinion that financial statements materially departing from a Board pronouncement conform to generally accepted accounting principles, within the meaning of the term "generally accepted" as used in a statute, ordinance, governmental regulation, order, ruling or opinion, or a contract between the audited organization and a third party, provided the auditor discloses the departure from the Board pronouncement and explains the meaning of "generally accepted" in circumstantial context.

The proposed amendment to the Code of Ethics presented a real dilemma. The overriding issues, as I view them, lay in the questions ( $\mathrm{I}$ ) whether the disclosure requirement was extended too far, (2) whether accountants could ever justify an opinion as to fair presentation of financial condition or operating results if that opinion were not related in a positive manner to the phrase "in accordance with generally accepted accounting principles," (3) whether specification of the APB as the exclusive source of generally accepted accounting priniples was too restrictive as well as unrealistic, (4) whether the profession was prepared to accept any authoritative arbiter in the place of the traditional standards of general acceptance, and (5) whether the Code of Ethics was the proper place to introduce so revolutionary and controversial a principle.

Whether one was, or is, "for" or "against" the policy embodied in the proposed amendment to Rule 2.02 (e), doubtless the proposal provoked, and has continued to provoke, among concerned members of the profession, more constructive soulsearching than at any other historical juncture. The only comparable period of introspection that I can think of is the time of constructive ferment and instructive self-criticism that followed upon the McKesson \& Robbins hearings. ${ }^{2}$ Whether or not it had previously been formulated in these specific terms, what was in fact involved was an attempt to define both the range and limitations of the profession's (and particularly the Board's) role in the development and promulgation of accounting principles. Whatever ambivalence, or contradiction if you will, had entered into the proposed amendment to Rule 2.02(e) attests to the fact that realism must be accommodated. The reference here is to two prime factors, either of which is not always consistent with the other, namely, $(a)$ the reservation to the indi-

\footnotetext{
${ }^{82}$ A summary of these hearings appears in McKesson \& Robbins, Inc., SEC Accounting Ser. Release No. I9, Dec. 5, 1940.
} 
vidual CPA of the ultimate exercise of professional judgment on substantive technical accounting matters, and (b) recognition that, as one Institute member commented, "the phrase 'generally accepted accounting principles' . . . has to an extent entered the public domain through inclusion in laws, regulations and private contracts"; the term 'generally accepted accounting principles" ; that term has a much broader base resting upon "sound business practices and upon the opinions of practitioners and teachers, of the stock exchanges, of SEC and regulatory authorities, of the courts, etc."

The principal thrust of the criticism by those opposing the measure was the inordinate added reporting responsibility; the multifarious meanings of "generally accepted accounting principles" that might develop; and the feeling that, if harmonious relations with the SEC could not be maintained as consistently as in the past, $^{55}$ the Institute might be setting itself on a "collision course," as one member phrased it. ${ }^{56}$

The Executive Committee's proposal catalyzed discerning discussion and debate by Council and Executive Committee members and among the Institute's membership generally. Leaving no stone unturned in seeking a sound solution, President Heimbucher in May 1964 appointed a Special Committee on Opinions of the Accounting Principles Board, which was charged with reviewing the entire matter of the status of APB opinions anew. After this committee completed the first of its instructed assignments, its recommendations were adopted by the Council in the fall of $1964{ }^{57}$ Briefly, the Council resolved that members should see to it that disclosure is made of departures from APB opinions and from effective Accounting Research Bulletins issued by the former Committee on Accounting Procedure. ${ }^{58}$ The new requirement is to take effect with respect to financial statements for fiscal periods beginning after December 31,1965 . The required disclosure may be made either in footnotes to the financial statements or in the audit report. Of particular importance is the requirement that the financial effects of the departure be shown in dollar amounts where practicable. The significant thing is that the new require-

${ }^{3}$ See Executrve Comm., op. cit. supra note 47 , at 20.

so Id. at $2 \mathrm{I}$.

${ }^{\circ}$ See Andrew Stewart, Accountancy and Regulatory Bodies in the United States r33-34, 137-38 (1937). For two other measured and discerning discussions, see Werntz, The Influence of Administrative Agencies on Accounting, 36 IowA L. REv. 270 (195I); Barr, The Influence of Government Agencies on Accounting Principles with Particular Reference to the Securities and Exchange Commission, Mich. C.P.A., March-April 1964, p. 5.

${ }^{\circ}$ See Executive Coms., op. cit. supra note 47 , app. A.

st AICPA, Disclosure of Departures from Opinions of Accounting Principles Board (Special Bull., I964).

${ }_{68}$ The Board was directed to review outstanding Accounting Research Bulletins by the end of $x 965$ in order to determine their proper status under the new disclosure requirements. Id. at I 7. The Board has carried out this assignment. Accounting Principles Bodrd, AICPA, Status of Accounting Research Bulletins (Opinion No. 6, I965). 
ments necessitate no change or qualification in the account's traditional opinion paragraph. The reporting accountant must still determine whether the statements "present fairly ... in accordance with generally accepted accounting principles ...."

Some members, to be sure, remain dissatisfied with the Council's decision in favor of the disclosure in question. Other members regard said disclosure as long overdue. Still others view the requirement as the natural culmination of the Institute's research effort and as proper recognition of the Institute's pronouncements as a reliable source of accounting authority. The Council's action in effect endorsed "disclosure of departures" as the minimum concession, or deference if you will, owed by a member to the deliberated recommendations of the body endowed with authority to make pronouncements on accounting matters for the guidance of Institute members. Equally important, it would seem, is the improvement in reporting standards by virtue of the point of reference provided by such disclosure, enabling readers of the financial statements to appraise the significance of departures from the norm (especially if the effect of any such departures can be measured and succinctly explained). There were times in the past, indeed, when an accountant's name was associated with statements on which no opinion was expressed, instances where there was no clear-cut indication of the character or extent of the examination, if any, made, and occasions where a qualified opinion or disclaimer was expressed without any statement of the reasons therefor. But these situations have been substantially cured by promulgation of explicit reporting standards, and, although for one reason or another there was much hue and cry when these standards were openly declared, there are few who would deny that the more refined reporting requirements have added immeasurably not only to the meaning, but also to the value and prestige, of the CPA's report.

Beyond the matter of disclosure, it should be stressed that a critical change lay in acknowledgment of the multiple sources of "generally accepted accounting principles." Thus, in the Special Bulletin informing the membership of the Council's action, the first three recommendations adopted by the Council read as follows:

т. "Generally accepted accounting principles" are those principles which have "substantial authoritative support.

2. Opinions of the Accounting Principles Board constitute "substantial authoritative support."

3. "Substantial authoritative support" can exist for accounting principles that differ from Opinions of the Accounting Principles Board.59

A final important aspect of the history just recounted is the relationship between the requirements set forth in the Council's Special Bulletin and the Institute's Code of Professional Ethics. The Council's action expressly dealt with the question of

\footnotetext{
${ }^{89}$ AicPa, Disclosure of Departures froms Opinions of the Accounting Principles Board (Special Bull. r964).
} 
the enforcement methods to be used in implementing the new disclosure requirement:

9. The failure to disclose a material departure from an Accounting Principles Board Opinion is deemed to be substandard reporting.t The Practice Review Committee should be instructed to give its attention to this area and to specifically report to Council the extent of deviations from these recommendations.

ro. The committee on professional ethics and the Institute's legal counsel have advised that the present By-Laws and Code of Professional Ethics would not cover an infraction of the above recommendations. Whether the Code of Professional Ethics should be amended is a question which should be studied further.

Subsequently, the Special Committee's final report recommended as follows:

A reasonable period of time having then elapsed for education and adaptation of the profession to Council's action in October 1964, regarding disclosure of departures from Opinions of the Board, Council in $x 968$ should approve, and propose to the membership of the Institute an amendment to the Code of Professional Ethics to cover infractions of these disclosure requirements. ${ }^{60}$

Thus, a prestigious committee of the Institute is on record as favoring the use of the Institute's ethics enforcement machinery to accord full recognition to APB actions. If the committee's proposal is ultimately adopted, a major step toward implementing increased uniformity will have been taken.

\section{The Future Outlook for APB Efforts}

The Institute's Special Committee on Opinions of the Accounting Principles Board concluded its functions with a final report in the spring of $1965 .{ }^{61}$ In addition to making recommendations respecting careful screening, composition, and tenure of Board membership, Board operational procedures, measures to be taken to facilitate understanding and acceptance of Board Opinions, and financing, the fortyone-page report made the following substantive recommendations:

I. At the earliest possible time, the Board should:

a. Set forth its views as to the purposes and limitations of published financial statements and of the independent auditor's attest function.

b. Enumerate and describe the basic concepts to which accounting principles should be oriented.

c. State the accounting principles to which practice and procedures should conform.

d. Define such phrases in the auditor's report as "present fairly" and "generally accepted accounting principles."

IIn discussion at the Council meeting it was explained that the phrase "substandard reporting" was used in the sense of reporting practices not in conformity with recommendations of the Council. [Footnote in original.]

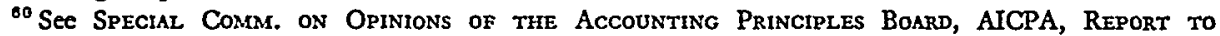
Council 30 (1965).

${ }^{81}$ See note 60 supra. 
e. Consider, with the committee on auditing procedure, the possibility of improving the terminology of the auditor's report, and in particular the words "generally accepted" in the expression "generally accepted accounting principles."

f. Define the words of art employed by the profession, such as "substantial authoritative support," "concepts," "principles," "practices," "procedures," "assets," "liabilities," "income," and "materiality."

2. The Board should move toward the reduction of alternative practices in accounting by adopting policies under which it will:

a. Recognize the objective that variations in treatment of accounting items generally should be confined to those justified by substantial differences in factual circumstances.

b. Set forth in its Opinions the criteria for application of such acceptable variations.

c. In an Opinion dealing with a situation which the Board believes justifies alternatives even though there is no significant difference in factual circumstances, set forth the treatment to be preferred, and require disclosure of the treatment followed.

The Board has already begun to accomplish some of the tasks included in this agenda and others recommended in the report. It has declared its intention to issue statements on the fundamentals of the reporting function, ${ }^{62}$ and three basic research studies on accounting concepts and principles are already available. ${ }^{63}$

For its bearing on the development and status of Board pronouncements and possible effect upon any future amendment to the Code of Professional Ethics, special mention should be made of Board member Herman W. Bevis' recent "Proposal for Accounting Principles Board to Consider Influences of Other Authorities on Accounting Principles." This proposal, as developed into a detailed prospectus by the AICPA's Accounting Research Division, envisions a long-term study of a widespread area of regulatory authority having a significant impact upon accounting principles, practice, and financial presentation. It is too early to know whether the Board will undertake this ambitious project, but, if accomplished, it would almost certainly result in a considerable systematized advance of knowledge and technique, in a much more refined concept of the weight and meaning properly attaching to considerations of public policy, and impact of the latter upon conventions and concepts which may be deemed within the purview of "generally accepted accounting principles."

\footnotetext{
62 J. Accountancy, Nov. I965, p. 20.

is See Maurice Moonitz, The Bastc Postulates of Accounting (AICPA Accounting Research Study No. I, I961); Robert T. Sprouse \& Maurice Moonitz, A Tentative Set of Brosd Accountino Principles for Business ENTERPRISEs (AICPA Accounting Rescarch Study No. 3, ig62); PAut Grudy, Inventory of Generatly Accepted Accounting Principles for Business Enterprises (AICPA Accounting Research Study No. 7, 1965).

"t Unpublished.
} 


\section{$\mathrm{V}$}

The Possible Roles of Government

The possibility of a greater role for government, primarily the SEC, has been regularly mentioned in the course of the debate over uniformity in financial reporting. ${ }^{65}$ Some have viewed this possibility as a threat to be averted and others as an inevitability. The probability is that any increase in government prescription of accounting methods will be proportional to the accounting profession's failure to show demonstrable progress. The SEC's role and the role of other regulatory bodies in the development of uniform accounting are discussed at length elsewhere in this symposium $^{68}$ and will not be dealt with here.

\section{A. Proposals for an "Accounting Court"}

This study of the institutional means of implementing improvements in financial reporting would not be complete without recognition of a recent proposal by a leading CPA firm for a federal "court of accounting appeals." A booklet recently published by Arthur Andersen \& Company ${ }^{67}$ sets forth the proposal and contains a draft of a statute that would bring such a court into being.

The agencies that would be made subject to the proposed statute are the Securities and Exchange Commission, the Federal Power Commission, the Interstate Commerce Commission, the Civil Aeronautics Board, and the Federal Communications Commission. In essence, the act would provide that certain interested persons could petition the named agencies to institute rule-making proceedings dealing with accounting matters and that, upon denial of such petition, or adverse decision on the merits after a hearing, an appeal could be taken to the "Court of Accounting Appeals." The court might then, in its discretion, institute original rule-making proceedings on a denied petition so appealed, or, adopt, modify, or repeal accounting rules made by an agency but appealed by a party to the agency proceeding. From a public policy standpoint, the proposed bill, in providing for initiation of rule making by an interested party, rather than, as is traditional in administrative law, confining initiation of such rule making to the agencies, stands counterpoised to the SEC's long-standing administrative policy of minimal rule making, leaving the development of accounting principles essentially within the hands of the profession. ${ }^{.8}$

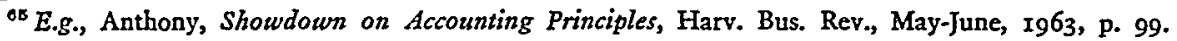

${ }^{60}$ See Pines, supra note $4 \mathrm{r}$, and Price, Walker \& Spacek, Accounting Uniformity in the Regulated Industries, supra, pp. 824-49.

${ }^{67}$ Arthur Andersen \& Co., Establishing Accounting Principles-A Crisis in Decision Making (1965).

${ }^{\circ}$ See Pines, supra note $4 \mathrm{r}$; address by SEC Commissioner Byron D. Woodside, $A$ Review of the Commission's Administrative Policies Relating to Financial Reporting Under the Securities Acts, before the Hayden, Stone Inc., Accounting Forum, New York City, Nov. 18, x965. See also note 55 supra.
} 
The AICPA's Executive Committee and Council will critically consider, develop, and state the Institute's official position on this proposal at an early date.

In connection with this proposal, it is of interest to note that a similar proposal was made in $193^{8}$ by A. A. Berle. ${ }^{69}$ Berle suggested at that time, early in the development of the SEC's policy toward accounting matters, the creation of an authoritative "Board of Accounting Appeals to which accounting questions could be referred, and which, by training, personnel, and equipment was capable of rendering swift decision on such problems." ${ }^{\prime 0} \mathrm{He}$ expressed concern lest the emergent accounting profession "abandon the collective responsibility for further evolution to the government agencies having power in the field," SEC, which he characterized as "the administrative agency having the greatest degree of control over the accounting profession save in a few specialized fields." He was particularly exercised over the fact that, at the time, as he put it, accounting questions were determined by the SEC "only as incidents to a stop-order proceeding" where a registrant who felt he was right had this sole alternative of "putting his honesty on trial" in determining an accounting matter that might plainly involve a difference of opinion rather than any question of intent to mislead. Berle thus pleaded for a procedure whereby "advisory opinions in advance of a controversy... or for general application"73 and guidance might be rendered. He expressed the hope "that accountants will continue to be fertile in theoretical and professional discussion" and urged the "slow, steady, self-critical erection of accounting theory.""74

While the motivations for these two proposals are not identical, the similarity in their substance is of more than passing interest.

\section{B. A Fundamental Thought on Governmental Implementation of Accounting Standards}

Generally accepted accounting principles and generally accepted auditing standards are inextricably bound up with each other. Current awareness of, and the obligation to adhere to, generally accepted accounting principles is a fundamental aspect of the accounting profession's auditing standards, which also include standards of competence, judgment, independence, integrity, and audit review responsibility. Discussion of effective means of implementing uniformity in accounting principles must recognize that the accountant's over-all professionalism is involved and that efforts to encroach upon that professionalism will not be well received and may be positively harmful. Usurpation by government of the accountant's professional

\footnotetext{
${ }^{98}$ Berle, Accounting and the Law, I3 Accounting Rev. 9 (1938), reprinted in Significant Accounting Essays 116 (Moonitz \& Littleton eds. 1965).

${ }^{70} I d$. at $x_{4}$.

II Id. at II.

12 Id. at 12.

${ }^{78}$ Id. at I4.

"Id. at $14^{-15}$.
} 
responsibility in this field might deprive accountants of the opportunity to achieve the final plateau of true professionalism. The result of achieving a higher degree of professional responsibility in the area of principles would undoubtedly carry over into every other phase of the accountant's work, including his performance of his auditing function.

For these reasons agencies of government would be well advised to stay their hands in the uniformity struggle until the profession's current efforts to narrow differences have had ample opportunity to bear fruit. Those agencies that are endowed with power to enforce accounting rules pursuant to their respective legal mandates are also crucially dependent on consistently high standards of performance by the profession. Even though endowed with plenary power, these agencies cannot do the whole job. From many standpoints, the agencies and the profession need each other.

Thus, not only in an idealistic sense but also in a very real and practical sense, the quality and degree of professional commitment within the accounting profession at large is apt to be determinative of the success of efforts to substitute uniform accounting principles for the multiplicity of existing principles for which one might summon up "substantial authoritative support." It is the AICPA's inescapable obligation and fundamental purpose to inculcate and encourage this commitment to the professional goal. 